\title{
Kronika Katedry Nauk Historycznoprawnych i Komparatystyki Prawniczej (rok 2016)
}

\section{Nowa nazwa i struktura Katedry}

W październiku 2016 r. Rada Wydziału Prawa UwB podjęła uchwałę o likwidacji funkcjonującej od 2013 r. Katedry Nauk Historyczno-Prawnych i Komparatystyki Prawniczej. W jej miejsce utworzono Katedrę Prawa Rzymskiego (kierownik prof. dr hab. Piotr Niczyporuk) oraz Katedrę Filozofii i Historii Prawa (kierownik prof. dr hab. Halina Święczkowska). Katedrę Prawa Rzymskiego tworzą Piotr Niczyporuk, Piotr Kołodko i Mariusz Mohyluk, natomiast pracownikami Katedry Filozofii i Historii Prawa zostali Piotr Fiedorczyk, Marcin Łysko i Karol Kuźmicz. Oprócz nich w Katedrze Filozofii i Historii Prawa znaleźli zatrudnienie pracownicy zlikwidowanego Zakładu Semiotyki Logicznej - Halina Święczkowska i Katarzyna Doliwa. Decyzją Dziekana Krzysztof Szczygielski został przeniesiony do Katedry Prawa Konstytucyjnego. W związku z przekształceniami strukturalnymi począwszy od 2017 roku kronika będzie prowadzona w ramach Katedry Filozofii i Historii Prawa, aczkolwiek uwzględnione w niej będą aktywność naukowa i osiągnięcia dotychczasowych pracowników Katedry Nauk Historycznoprawnych i Komparatystyki Prawniczej.

\section{Publikacje}

Efektem aktywności naukowej pracowników Katedry w 2016 r. były liczne publikacje krajowe i zagraniczne, spośród których wyróżniają się dwie monografie. Nakładem wydawnictwa Temida 2 ukazała się monografia Marcina Łysko Prace nad kodyfikacja materialnego prawa wykroczeń w Polsce Ludowej (1960-1971). Książka została wskazana przez autora jako osiągnięcie naukowe we wszczętym w dniu 1 września 2016 r. postępowaniu habilitacyjnym. Na bazie ukończonej rozprawy doktorskiej Kamil Niewiński przygotował monografię PZPR a sądownictwo w latach 1980-1985. Próby powstrzymania "solidarnościowej" rewolucji, która została opublikowana przez oświęcimskie wydawnictwo Napoleon V. W ramach zespołu naukowego zajmującego się opracowaniem i przetłumaczeniem na język polski Digestów Justyniańskich Piotr Niczyporuk współredagował publikację Digesta Iustiniani. Digesta justyniańskie, tekst i przekład, t. VI.1 (księgi 37-40), red. Tomasz Palmirski, Kraków 2016. W Encyklopedie českých práuních dějin, red. K. Schelle, J. Tauchen, Plzeň-Ostrava 2016, Piotr Fie- 
dorczyk zamieścił rozdział Legislativní českoskovensko-polská spolupráce (1949). Napisany przez niego wspólnie z A. Zemke-Górecką tekst Polish family law: socialist roots, astonishing evolution został opublikowany $\mathrm{w}$ dziele The International Survey of Family Law: 2016 edition, red. B. Atkin, F. Banda, Bristol: Jordan Publishing.

Pracownicy Katedry byli autorami kilkunastu artykułów, które zostały opublikowane na łamach zagranicznych i krajowych periodyków naukowych, wydawnictw pokonferencyjnych oraz ksiąg pamiątkowych. Artykuł Piotra Fiedorczyka Kilka uwag o genezie ustawy z dnia 13 lipca 1939 r. o ułatwieniu przysposobienia małoletnich ukazał się w "Studia Iuridica Lublinensia” (2016, t. 25, nr 3). Na łamach periodyku „Iustitia” (2016, nr 3) Kamil Niewiński opublikował artykuł Represje kadrowe wymierzone w sędziów w okresie stanu wojennego. Kolejne opracowanie jego autorstwa Sądy pod presja władz zostało zamieszczone w dodatku "Zbrodnie stanu wojennego", który ukazał się łącznie z poświęconym 35 rocznicy wybuchu stanu wojennego numerem 50/2016 tygodnika "W Sieci”. W czasopiśmie „Edukacja Prawnicza” (2016, nr 1) Krzysztof Szczygielski opublikował artykuł Adam Mickiewicz i prawo rzymskie.

W ramach materiałów pokonferencyjnych ukazały się artykuły Piotra Fiedorczyka Historia i wspótczesność prawa rodzinnego na ziemiach polskich w pogladach księdza Michała Sopoćki (w: Stefan Ehrenkreutz i historycy prawa okresu dwudziestolecia międzywojennego. W 70. rocznicę śmierci ostatniego Rektora Uniwersytetu Stefana Batorego w Wilnie, red. P. Dąbrowski, D. Szpoper, Gdańsk-Olsztyn 2016) oraz Polish and Czechoslovak Regulations on the Adoption Law in Period 1928-1950 (w: Judiciary and Society between Privacy and Publicity. 8th Conference on Legal History in the Baltic Sea Area, 3rd-6th September 2015, Torun, red. D. Janicka, Torun 2016). Ponadto Piotr Fiedorczyk zamieścił artykuł Z dziejów stalinizacji polskiej nauki prawa: Komisja Konsultacyjno-Naukowa przy Ministrze Sprawiedliwości (1949-1951) w księdze pamiątkowej Profesora Andrzeja Zięby Konstytucjonalizm, doktryny, partie polityczne (red. R. Kłosowicz, B. Kosowska-Gąstoł, G.M. Kowalski, T. Wieciech, Ł. Jakubiak, Kraków 2016). W księdze jubileuszowej Profesor Marii Zabłockiej Mater Familias: scritti romanistici per Maria Zabłocka (Warszawa 2016, red. Z. Benincasa, J. Urbanik) ukazał się artykuł Piotra Kołodko Some comments on the role of the quaestor as a prosecutor in criminal proceedings in the times of the Roman Republic.

\section{Konferencje naukowe}

Istotnym aspektem aktywności pracowników Katedry był udział w zagranicznych i krajowych konferencjach naukowych. Dwukrotnie w zagranicznych konferencjach naukowych uczestniczył Piotr Niczyporuk. We wrześniu 2016 r. brał udział LXXe Session de la SIHDA 2016. Ius et Periculum. Le droit face au risque dans l'Antiquité (Paryż 13-17 września 2016 r.). Z kolei na początku li- 
stopada 2016 r. uczestniczył w XII Seminario internazionale „Diritto Romano e Attualità" (Bratysława 3-5 listopada 2016 r.) na temat Le procedure giudiziali nella Roma antica e nell'attualità tra gli interessi pubblici e privati, wygłaszając referat La capacità giuridica e la tutela del nascituro nel diritto romano. W seminarium tym uczestniczył także Piotr Kołodko, który zaprezentował referat The role of quaestor as a prosecutor in criminal proceedings in the ancient Rome.

Marcin Łysko brał udział w XXII th Annual Forum Association of Young Legal Historians (Belgrad 6-8 maja 2016 r.), występując z referatem Forms of law-making in Poland in the 20th century. Uczestnicząc w 4 th Biennal Conference of European Society for Comparative Legal History (Gdańsk - Gdynia 28 czerwca-1 lipca 2016 r.) wygłosił referat Political circumstances of adjudicating on petty offences in the People's Republic of Poland.

Na szczególne podkreślenie zasługuje udział pracowników Katedry w pracach związanych z organizacją Międzynarodowej Konferencji Naukowej Rodzina a prawo w cywilizacji chrześcijańskiej, która odbyła się w leżącym nieopodal Białegostoku, Supraślu w dniach 19-21 maja 2016 r. Oprócz prelegentów reprezentujących polskie uniwersytety $\mathrm{w}$ konferencji wzięli udział naukowcy z Sankt-Petersburga i Rzymu. Funkcję przewodniczącego Komitetu Organizacyjnego pełnił Piotr Niczyporuk. Podczas konferencji obradom sekcji przewodniczyli Piotr Fiedorczyk oraz Mariusz Mohyluk, natomiast z referatami wystąpili Marcin Łysko (Odpowiedzialność karna rodziców w prawie wykroczeń Polski Ludowej) i Karol Kuźmicz (Rola rodziny we francuskich utopiach oświeceniowych: Mably, Meslier, Morelly).

Podczas XXVI Zjazdu Historyków Państwa i Prawa oraz Historii Doktryn Polityczno-Prawnych (Mrągowo 13-16 września 2016 r.) białostockie środowisko historyczno-prawne reprezentował Piotr Fiedorczyk. Przewodniczył obradom jednej z sesji Zjazdu oraz wygłosił referat Próby nowelizacji t. X cz. I Zwodu Praw Cesarstwa Rosyjskiego w II RP. Ponadto Piotr Fiedorczyk został zaproszony do Senatu RP na posiedzenie Polskiego Towarzystwa Legislacji, gdzie w dniu 8 grudnia 2016 r. zaprezentował referat Stanowienie prawa w II RP.

Spośród pracowników Katedry najczęściej w krajowych konferencjach naukowych uczestniczył Krzysztof Szczygielski. Podczas XII Colloquium Prawno-Historycznego Edukacja prawnicza od Bejrutu do Bolonii (Brzeg 10-11 maja 2016 r.), wygłosił referat Nauczanie prawa rzymskiego w Wolnej Wszechnicy Polskiej w okresie dwudziestolecia międzywojennego. Brał także udział w Konferencji Naukowej „Unormowania odpowiedzialności w systemach prawnych” (Warszawa 3 czerwca 2016 r.), prezentując wystąpienie Odpowiedzialność za wychowanie dziecka w prawie polskim i kanonicznym. Kolejny referat Prawo rzymskie w pracach nad Kodeksem zobowiązań z 1933 r. wygłosił na posiedzeniu Sekcji Praw Antycznych Komitetu Nauk o Kulturze Antycznej PAN (Warszawa 22 czerwca 2016 r.). Podczas Ogólnopolskiej Konferencji Naukowej „Gaius noster. Polskie studia nad «Instytucjami Gaiusa» w latach 1816-2016" (Lublin 17-18 paździer- 
nika 2016 r.), wystąpił z referatem Kilka uwag na temat studiów Adama Mickiewicza nad Instytucjami Gaiusa. W konferencji tej uczesnticzyli również Piotr Niczyporuk i Piotr Kołodko, którzy wspólnie zaprezentowali referat Teodor Dydyński - romanista i tłumacz Instytucji Gaiusa.

Dwukrotnie w krajowych konferencjach naukowych w charakterze referanta uczestniczył Karol Kuźmicz. Podczas XVI Konferencji Naukowej Przyjaźń oraz inne więzi międzyludzkie (Kuźnica na Helu 22-25 kwietnia 2016 r.) wygłosił referat $O$ potrzebie przewartościowania relacji międzyludzkich w "Testamencie" Jana Mesliera. Brał także udział w Konferencji Naukowej Wielokulturowość czy uniwersalizm wartości (Nałęczów 6-8 czerwca 2016 r.), prezentując wystąpienie Uniwersalizm wartości utopii społecznych. W Ogólnopolskiej Konferencji Naukowej Historia państwa i prawa - w kręgu aktualnych kierunków badań (Łódź 25 kwietnia 2016 r.) uczestniczył Marcin Łysko z referatem Prawo wykroczeń Polski Ludowej jako przedmiot badań historycznoprawnych. Z okazji Dni Wymiaru Sprawiedliwości 23 maja 2016 r. w Sądzie Rejonowym w Białymstoku Kamil Niewiński zaprezentował referat Represje kadrowe wymierzone w sędziów w okresie stanu wojennego $i$ w latach następnych (1981-1985).

Piotr Niczyporuk i Piotr Kołodko uczestniczyli w Międzynarodowej Konferencji Naukowej „Mater familias” (Warszawa 1 października 2016 r.), podczas której miało miejsce wręczenie Profesor Marii Zabłockiej księgi jubileuszowej. W dniu 3 grudnia 2016 r. Piotr Niczyporuk brał udział w posiedzeniu plenarnym Komitetu Nauk o Kulturze Antycznej PAN. Natomiast Piotr Kołodko dwukrotnie (w dniach 15 lutego i 22 czerwca 2016 r.) uczestniczył w obradach Sekcji Praw Antycznych Komitetu Nauk o Kulturze Antycznej PAN.

\section{Udział pracowników Katedry w przewodach doktorskich i postępowaniach habiltacyjnych}

W 2016 r. Piotr Fiedorczyk dwukrotnie uczestniczył w postępowaniach habilitacyjnych. W toczącym się przed Radą Wydziału Prawa i Administracji Uniwersytetu Śląskiego postępowaniu habilitacyjnym dr Anny Stawarskiej-Rippel pełnił funkcję recenzenta. W postępowaniu habilitacyjnym dr. Karola Łopateckiego, które toczyło się przed Radą Wydziału Prawa UwB, uczestniczył w charakterze sekretarza komisji habilitacyjnej. Recenzował także rozprawę doktorską Barbary Kwiatkowskiej, napisaną pod kierunkiem dr. hab. Zdzisława Zarzyckiego na Wydziale Prawa i Administracji UJ.

Z dniem 1 października 2016 r. Piotr Fiedorczyk objął funkcję kierownika studiów doktoranckich na Wydziale Prawa UwB. W roku akademickim 2016/2017 na kierowanym przez niego studium doktoranckim studiowało około 170 osób. 